\title{
Genotype x Environment Interaction for reproductive traits in brazilian Nellore breed cattle
}

\author{
Interação Genótipo x Ambiente para características reprodutivas em bovinos da raça \\ Nelore no brasil
}
CARVALHO, Caio Victor Damasceno ${ }^{1 *}$; COSTA, Raphael Bermal2 CAMARGO, Gregório Miguel Ferreira de²; BITTENCOURT, Thereza Cristina Calmon²

1 Universidade Federal do Oeste da Bahia, Centro Multidisciplinar de Barra, Barra, Bahia Brasil.

${ }^{2}$ Universidade Federal da Bahia, Escola de Medicina Verinária e Zootecnia, Salvador, Bahia, Brasil.

*Endereço para correspondência: caio.carvalho@ufob.edu.br

\section{SUMMARY}

The objective of this study was to evaluate the effect of the genotype-environment interaction (GEI) for scrotal circumference traits measured at different ages, 365 (SC365), 450 (SC450) and 550 (SC550) days of age, and age at first calving (AFC) for Nellore animals raised in different regions of Brazil. For the evaluation, the herds were grouped in the following regions of the country: North, Southeast and Central-west, using information from $26,619,28,730,14,476,15,397$ for the traits SC365, SC450, SC550 and AFC respectively. Genetic parameters, as well as the assessment of GEI were performed using Bayesian inference, using the programs of the BLUPF90. The estimated heritabilities were: $0.465 \pm 0.021,0.500 \pm$ $0.022,0.492 \pm 0.026,0.117 \pm 0.017$ for SC365, SC450, SC550 and AFC respectively. The results obtained in the analysis, indicated that this interaction was not significant for SC at different ages (genetic correlation, $\mathrm{rg}>0.8$ ). For AFC, significant effect of GEI was observed for combinations involving the Northern region $(\mathrm{rg}<0.8)$, indicating that this interaction should be considered by the genetic evaluation programs in this region.

Keywords: Genetic correlation, Bos indicus, heritability, Beef cattle

\section{RESUMO}

O presente estudo teve como objetivo avaliar o efeito da interação genótipoambiente (IGA) para as características perímetro escrotal mensurado em diferentes idades, 365 (PE365), 450 (PE450) e 550 (PE550) dias de idade, e da idade ao primeiro parto (IPP) para animais da raça Nelore criados em diferentes regiões do Brasil. Para a avaliação foram agrupados os rebanhos dos diferentes estados do país, nas seguintes regiões: Norte, Sudeste e CentroOeste, sendo utilizados informações de 26619, 28730, 14476, 15397 para as características PE365, PE450, PE550 e IPP respectivamente. Os parâmetros genéticos, assim como, a avaliação da IGA foi realizada utilizando a inferência Bayesiana, com uso dos programas BLUPF90. As herdabilidades estimadas foram: $0,465 \pm$ $0,021,0,500 \pm 0,022,0,492 \pm 0,026,0,117$ $\pm 0,017$ para PE365, PE450, PE550 e IPP respectivamente. Os resultados obtidos indicaram que a interação não foi significativa sobre o perímetro escrotal avaliado nas diferentes idades (correlação genética, $r_{\mathrm{g}}>0,8$ ). No entanto, para a IPP foi evidenciado efeito significativo da IGA para as combinações envolvendo a região Norte $\left(\mathrm{r}_{\mathrm{g}}<0,8\right)$, indicando que esta interação é significativa devendo ser considerada pelos diferentes programas de 
avaliação genética da raça,para os animais criados nesta região.
Palavras-chave: Correlação genética, Bosindicus, herdabilidade, bovinos de corte 


\section{INTRODUCTION}

The Nellore breed stands out in Brazil, because it presents the greatest genetic contribution to the herd, which is estimated in 218.25 million cattle (IBGE, 2016). According to OLIVEIRA et al., (2002), $80 \%$ of this population is composed by genes of this breed and its crosses. Because of that, it is considered an important breed for beef cattle breeding in the tropical region and for the meat supply in the world.

The Brazilian territory is vast, presenting regions with different climatic conditions and varied production systems. Such scenario lead to different performances of genotypes, which characterizes the genotypeenvironment interaction (GEI).The importance of internal migration of bovine populations was pointed out by McManus et al. (2016). That work highlights the importance of evaluating the GEI to better define the sires to be selected, given the trend of movement between different regions.

Among the objectives of the selection for Nellore herds in Brazil, the reproductive traits present economic importance for the success of the activity, as can be observed in the studies developed by Brumatti et al. (2011), Jorge Júnior et al. (2007), and Carvalho \& Bittencourt (2015). In beef cattle, the reproductive evaluation of cows is based on the number of calves born annually, leading to the increase in the number of calf/year and the number of calf/cows along the reproductive life (CHUD et al. 2014).

Evidences for the presence of GEI in development traits have already been demonstrated for the Nellore breed in Brazil - between different regions of a State, between States or between the different regions of the country (TORAL et al. 2004; PÉGOLO et al.
2009 e DIAZ et al. 2011).Carvalho et al. (2013) evaluated the presence of GEI in the Nellore breed for the development traitsW210 and W365 between the Center-West, North, and Southeast regions of Brazil, emphasizing their presence between the North and Southeast regions when W365 was evaluated. Other works have reported similar results, such as those performed by Chiaia et al. (2015), Lemos et al. (2015), and Ambrosini et al. (2016).

Due the economic importance of reproductive traits for Nellore, the aim of this study was to evaluate the GEI via Bayesian inference in the scrotal perimeter traits, at different ages and the age at first calving in heifers among herds distributed in the Brazilian Central-west, North, and Southeast.

\section{MATERIAL AND METHODS}

For the development of the present study, the phenotypic information of Nellore animals participating in the Nellore Brazil Genetic Breeding Programwere used. This tool was managed by the National Association of Breeders and Researchers (ANCP). The animals used in this work were born between 2001 and 2009The commercialization of animals for slaughter and the production of genetically superior breeds and breeding herds are the main objectives of the production of herds. The animals were kept in pastures throughout the year, receiving mineral supplementation and water ad libitum.Females were submitted to a mating season with duration of 90 to 120 days, submitted to artificial insemination or controlled mating. Weaning was carried out around 6 to 8 months.

The database used was constructed using information from herds raised in 
several regions of Brazil, however, information from the states with the highest number of animalswere used. In order to characterize the breeding environment, the states were grouped according to their geographical location. In this way, the database used in the analyzes was composed by farms distributed between the Central-West (Goiás, Mato Grosso do Sul, Mato
Grosso), North (Tocantins, Pará, and Rondônia), and Southeast (São Paulo and Minas Gerais). The scrotal perimeter was adjusted to the following ages: 365 days (SC365), 450 days (SC450), 550 days (SC550), andat first calving of heifers (AFC). The number of animals evaluated in each region is shown in Table 1.

Table 1.Descriptiv estatistics

\begin{tabular}{cccc}
\hline Traits & Region & N $^{\circ}$ of animals & Mean \pm SD \\
\hline SC365 & Central-west & 15,600 & \\
& North & 4,822 & $20.42 \pm 2.15 \mathrm{~cm}$ \\
& Southeast & 6,197 & \\
& Total & $\mathbf{2 6 , 6 1 9}$ & \\
SC450 & Central-west & 17,115 & \\
& North & 5,050 & $23.34 \pm 2.93 \mathrm{~cm}$ \\
& Southeast & 6,565 & \\
SC550 & Total & $\mathbf{2 8 , 7 3 0}$ & \\
& Central-west & 8,985 & \\
& North & 1,898 & $26.48 \pm 3.45 \mathrm{~cm}$ \\
& Southeast & 3,593 & \\
& Total & $\mathbf{1 4 , 4 7 6}$ & \\
& Central-west & 10,465 & \\
& North & 2,173 & $1107.25 \pm 159.36$ days \\
& Southeast & 2,759 & \\
& Total & $\mathbf{1 5 , 3 9 7}$ & \\
& & &
\end{tabular}

The original data were edited usingSAS 9.2 program (SAS Inst., Inc., Cary, NC) that contained information on 146,536 animals. However, in order to set the information necessary for the present study, some restrictions were made: birth seasons (1- December to February, 2 - March to May, 3 - June to August, 4 - September to November), contemporaneous groups (CG) with information on the breeding farm creation, management group (GROUP 365,450 and 550), season and year of birth. Data from animals that exceeded the mean \pm 3 standard deviations for the traits of interest, CG information with less than 3 animals, and information from breeding animals with less than 5 calf were excluded. The genetic connection between the evaluated enviroments was guaranteed.

The first database was used in order to estimate the genetic parameters for the traits evaluated. It was composed by the following information: identification of the animal, identification of the bull and cow, CG for the different ages of perimeter scrotal and age at first calving (CGSC365, CGSC450, CGSC550, CGAFC), SC365, SC450, SC550, and AFC. However, to verify the presence of the genotype-environment interaction (GEI)were created separated files, where the studied trait is considered 
different for each breeding environment.That way, other fourfiles containing the following information were created: the identity of the animal, bull and cow, CG for the trait, trait $\mathrm{X}$ in the North region, trait $\mathrm{X}$ in the Southeast region, andtrait $\mathrm{X}$ in the Center-West region. The pedigree file contained the information about the identity of the animal, bull, and cow.

Initially, a multi-trait evaluation was performed to estimate the genetic parameters of the traits.After that, the analyzes were performed to verify the

$$
y=X \beta+Z a+e
$$

where, y, $\beta, a$ and $e$ arethe vector of observations, vector of the systematic effects (would be the fixed ones), vector of direct additive genetic effects, and vector of random errors, respectively. $\mathrm{X}$ and $\mathrm{Z}$ are, respectively, the incidence matrices that associate $\beta$ and $\alpha$ to the observations.

The vectors $\beta$ and $\alpha$ are the lease parameters of a conditional distribution presence of the GEI, in this case, a multi-traits analysis was used. In the model used the fixed effects were controlled through the creation of the contemporaneous group (CG for each of the traits) and the random effects are considered additive genetic directstudied for each traits SC365, SC450, SC550, and AFC. The data were analyzed usingGIBBS2F90 program (MISZTAL et al., 2014).

In matrix form, the general model can be described as:

$$
y \mid \beta, a, R \sim N[X \beta+Z a, I N R] \text { (VAN TASSEL\& VAN VLECK, 1996). }
$$

A total of $1,000,000$ samples were generated with a burn-in period of 300,000 , with samples taken every 50 cycles. Convergence was verified using the POSTGIBBSF90 program (MISZTAL, 2014). The means of the a posteriori variances estimated for each trait were used for the estimation of heritabilities and a posteriori mean correlations.

According to Robertson et al. (1959), the GEI investigationwas verified when the genetic correlation (rg) between the traitswas less than 0.8. However, to verify this correlation, the same trait as a distinct trait in each of the different breeding environments must be considered. $\mathrm{y} \mid \beta, \alpha$. It was considered, a priori, that $\beta$ has a uniform distribution, which reflects vague preliminary knowledge about this vector. Inverted Wishart distributions were assigned to the other components (random effects). Thus, the distribution of $y$, given the parameters of the location and scale, was considered as:

\section{RESULTS}

High heritability estimates $\left(h^{2}\right)$ were found in the multi-trait evaluation (Table 2) for the scrotal perimeter adjusted for the ages invastigated $\left(\mathrm{h}^{2}>\right.$ 0.4). So, significant selection gains are expected for this trait, as well as, the additive genetic effects have an important contribution to the performance of the scrotal perimeter in the evaluated herds. However, at the age of the first calving (AFC) the estimated $\mathrm{h}^{2}$ was of low magnitude $\left(\mathrm{h}^{2}<0.2\right)$, proving the low effect of the additive genetic components indicating that nonadditive genetic and environmental 
effects (management and climate) are more pronounced.

Regarding the genetic correlation between the traits evaluated, it can be observed in Table 3 that there is a high correlation in the scrotal perimeter measurements ( $\mathrm{rg}>0.8$ ), indicating that the same gene groups are acting on the traits at different ages. However, when the genetic correlation between the perimeter measures in males and the age at first calving of heifers was evaluated, it was verified that there was a negative correlation for the combination between all ages of SC and AFC, indicating that the genetic groups that lead to the increase of the performance for a trait act decreasing the performance of the other. In the case studied, the genes that are responsible for the increase of the scrotal perimeter of males at different ages are also responsible for determining the decreasing of the age at the first calving heifers.

Table 2. Estimates of the variance components and heritability

\begin{tabular}{c|ccccc}
\hline $\boldsymbol{\sigma}_{\mathbf{a}}^{\mathbf{2}}$ & $\boldsymbol{S C 3 6 5}$ & $\boldsymbol{S C 4 5 0}$ & $\boldsymbol{S C 5 5 0}$ & $\boldsymbol{A F C}$ & $\boldsymbol{h}^{2} \pm \boldsymbol{S E}$ \\
\hline $\boldsymbol{S C 3 6 5}$ & 1.4715 & 1.954 & 2.0367 & -11.308 & $0.465 \pm 0.021$ \\
$\boldsymbol{S C 4 5 0}$ & & 2.8317 & 3.1049 & -14.175 & $0.500 \pm 0.022$ \\
$\boldsymbol{S C 5 5 0}$ & & & 3.7303 & -20.186 & $0.492 \pm 0.026$ \\
$\boldsymbol{A F C}$ & & & & $2,069.4$ & $0.117 \pm 0.017$ \\
\hline $\boldsymbol{\sigma}_{\mathrm{e}}^{\mathbf{2}}$ & $\mathbf{S C 3 6 5}$ & $\mathbf{S C 4 5 0}$ & $\mathbf{S C 5 5 0}$ & $\boldsymbol{A F C}$ & \\
\hline $\boldsymbol{S C 3 6 5}$ & 1.6863 & 1.6028 & 1.404 & 0 & \\
$\boldsymbol{S C 4 5 0}$ & & 2.8243 & 2.6055 & 0 & \\
$\boldsymbol{S C 5 5 0}$ & & & 3.849 & 0 & \\
$\boldsymbol{A F C}$ & & & & 15,543 & \\
\hline
\end{tabular}

Table 3. Genetic correlations (above the main diagonal) and phenotypic correlations (below the main diagonal) between the traits in the multicarter analysis

\begin{tabular}{c|cccc}
\hline & SC365 & SC450 & SC550 & AFC \\
\hline SC365 & 1.0 & 0.96 & 0.87 & -0.20 \\
SC450 & 0.60 & 1.0 & 0.96 & -0.19 \\
SC550 & 0.19 & 0.41 & 1.0 & -0.23 \\
AFC & -0.70 & -0.75 & -0.42 & 1.0 \\
\hline
\end{tabular}

In order to verify the existence GEI for scrotal circumference measured at different ages, a evaluation of multitraits was performed and no interaction was observed (Table 4). However, for
AFC, the presence of GEI was found between the North and Central-west regions as well as North and Southeast regions ( $\mathrm{rg}<0.8)$. 
Table 4. Genetic correlations ( $\mathrm{rg}$ ) among the traits considered as different in each breeding region

\begin{tabular}{clccc}
\hline Trait & & Central-west & North & Southeast \\
\hline SC365 & Central-west & 1.0 & 0.98 & 0.92 \\
& North & & 1.0 & 0.84 \\
& Southeast & \multirow{2}{*}{1.0} & 0.95 & 1.0 \\
SC450 & Central-west & & 1.0 & 0.96 \\
& North & & & 0.88 \\
& Southeast & \multirow{2}{*}{1.0} & 0.82 & 1.0 \\
SC550 & Central-west & & 1.0 & 0.99 \\
& North & & & 0.88 \\
& Southeast & \multirow{2}{*}{1.0} & $\underline{\mathbf{0 . 2 1}}$ & 1,0 \\
& Central-west & & 1.0 & 0.94 \\
& North & & $\mathbf{0 . 5 2}$ \\
& Southeast & & & 1.0 \\
\hline
\end{tabular}

\section{RESULTS AND DISCUSSION}

The results found in the descriptive analysis (Table 1), for SC at different ages $(20.42-26.48 \mathrm{~cm})$ and AFC (1107.25 days), are in accordance with the values reported in the literature for the Nellore breed (BOLIGON et al. 2007; MATOS et al. 2013; LEMOS et al. 2015; SOUSA et al. 2015; AMBROSINI et al. 2016; BUZANSKAS et al. 2017). These works showed mean values that ranged from 20.13 to $31.88 \mathrm{~cm}$.

Although scrotal perimeter measures do not present direct economic benefits, they have been used by the genetic improvement programs. That happens because of their association with the reproductive capacity of bulls and cows, as well as being related to growth traits (FORTES et al. 2012; SIQUEIRA et al. 2013; BUZANSKAS et al. 2017). Heritability values obtained in the multi-trait evaluation (Table 2), for the SC measurements at different ages were of high magnitude, ranging from 0.465 0.50 that are in line with results published for the same breed by Raidan et al. (2015), Chiaia et al. (2015), and Buzanskas et al. (2017).

However, Boligon et al. (2007) estimated $\mathrm{h}^{2}$ values for SC365 and 550 equal to 0.25 and 0.37 , respectively. In other words, the values found were lower than those present in the literature for the Nellore breed. According to the same author, low estimates of $h^{2}$ for the scrotal perimeter may be caused by the inadequate adjustment of the perimeter by the age of the animal at the time of measurement. SC heritability values for animal at different ages found in this paper, and also observed in other works, pointed out that $h^{2}$ is from moderate to high magnitudes. Also, SC is highly correlated for theses ages with correlation values greater than 0.85 .

Therefore, the selection of males for this trait can be performed at younger ages, which would increase the genetic gains and reduce the maintenance cost of young bulls that are candidates for selection. According to Siqueira et al. (2013), genetic evaluation programs have adopted the standard age of selection for SC at 18 months.

The Nellore breed is considered sexually late. In an attempt to anticipate 
the age of puberty as well as to reduce the age at first calving, by increasing its useful life in the herd, selection works have been intensified. The identification of earlier animals enables cows having a greater number of progenies during their life produced. Thus, AFC has been included as a selection criterion for the Nellore breed in Brazil. Despite having low heritability, it presents genetic variability and potential to be improved with the use of selection, mainly due to the greater selective intensity applied to the females (MATOS et al., 2013).

Genetic variability is confirmed by $\mathrm{h}^{2}$ value estimated to be 0.117 (Table 2). Other studies corroborated the low magnitude of $h^{2}$ for this trait in the Nellore, as the results showed by Sousa et al. (2015) with animals raised in the middle northern region of Brazil. In that work, an estimate of $h^{2}$ equal to 0.026 was obtained, evidencing that the additive genetic effects are not very pronounced for the performance of this trait. The estimated $h^{2}$ value found in the present study is higher than that one presented by Sousa et al. (2015). This finding may be related to the fact that the animals were submitted to different environmental and management factors of the herds, combined with the fact that the management and age at which females were introduced in reproduction are directly related to age at the first birth.

However, other studies obtained estimates with similar magnitude found in the present work, for instance, Boligon et al. (2008) found estimates of $\mathrm{h}^{2}$ ranging from $0.14-0.15$, Pereira et al. (2010) evaluated animals of the same breed in which values between 0.06 0.10 were presented, Chiaia et al. (2015) verified that the $\mathrm{h}^{2}$ for the AFC varied between $0.09-0.50$, depending on the environmental gradient to which the animals were submitted, and
Ambrosini and collaborators (2016) who found $h^{2}$ equal to $0.06 \pm 0.02$. These values are due to the locations and management adopted in the herds, and some of the animals evaluated in these studies were distributed among the Southeast, Central-west and Northeast regions of Brazil. Buzanskas et al. (2017) found $h^{2}$ values equal to $0.25 \pm 0.02$ for Nellore animals found in Brazil, which is of moderate magnitude and is higher than that one found in the present study.

However, low estimates of $\mathrm{h}^{2}$ for different birth ages, especially for the age at first calving, may be a consequence of the criteria adopted for the entry of the heifers in the reproduction, especially those related to weight and age. Normally, it is expected that the heifers reach a satisfactory body condition to be exposed to the bull or to be inseminated, initiating the reproductive activity (BOLIGON et al., 2007; MELLO et al., 2016).

For Chiaia et al. (2015), the variation of variance components and estimates of $\mathrm{h}^{2}$ in different breeding environments can be explained by many reasons. The $\mathrm{h}^{2}$ parameter is a property of the population and the environment, while the environmental variance is dependent on the general management conditions and climate. In general, greater variations of environmental conditions reduces $\mathrm{h}^{2}$, while greater environmental uniformity increases heritability (TORAL et al., 2004).

The identification of females that have the capacity to gestate at younger ages is one of the priorities of selection and breeding programs in the Nelore breed (FARIA et al., 2009). Studies to determine genetic correlations between $\mathrm{SC}$ and reproductive traits of cows have been developed, in order to overcome the greatest difficulty in determining easily measurable traits that are 
genetically associated with female fertility (SIQUEIRA et al. 2013). With this purpose, the genetic and phenotypic correlations between the studied traits were estimated (Table 3 ).

However, due to the absence of measurements of some animals at different ages, the phenotypic correlation presented the greatest variability for their results. The value of genetic correlations between the different ages of the scrotal perimeter is confirmed by the results obtained by Buzanskas et al. (2017), which was equal to 0.94. However, when the values of genetic correlation between the measurements of SC and AFC were observed, they were phenotypically and genetically negatively correlated. These negative genetic correlations indicate that the gene groups that act to promote greater SC measurements act to reduce the AFC in the daughters of reproductive animals ( $\mathrm{rg}$ between -0.19 to -0.23 ). These results suggested that the selection of the earliest females can be performed indirectly through the evaluation of the SC of the breeders, these results are similar to those obtained by Ferraz and Eler (2007), who obtained an estimate of negative genetic correlation, -0.40 , between the SC450 and the AFC of the heifers. Boligon et al. (2007) evaluated the correlations between Nellore traits and genetic correlations between SC12 and SC18 months with AFC, with values equal to -0.13 and -0.23 , respectively. This finding was also corroborated by Buzanskas et al (2017) who found values of genetic correlations between scrotal circumference at different ages with the AFC of -0.50 and -0.46 , for SC365 and SC450, respectively. According to Boligon et al. (2007), these results showed that the selection of breeding herds for a greater scrotal circumference provides, as a correlated response, lower age at the first calving of their offspring. This reduction in AFC may be faster when selected for the most strongly associated ages, in the specific case of this study, SC550 selection is recommended. Irano et al. (2016) when studying both traits in genome-wide association study, in cattle of the same breed, found that the major genes that affect SC are not the same ones that affect AFC and vice versa, suggesting that the genetic correlation is caused by pleiotropic genes with less effect.

The evaluation of the GEI (Table 4) for the scrotal perimeter demonstrated that no results were found that show the presence of the interaction between the regions studied, rg greater than 0.80 for all the combinations between the three regions. These results are confirmed by Matos et al. (2013), Chiaia et al. (2015), Lemos et al. (2015), and Raidan et al. (2015), which evaluated Nellore herds distributed among the different Brazilian regions and found no evidence of interaction, all the studies used the measurements of scrotal perimeter at 18 months.

This fact can be explained by the high heritabilities found for the traits, showing less influence of the environment. In this way, by combining the results found in this study with those of the cited authors, it can be concluded that for the trait scrotal perimeter the genetic evaluation programs of the Nellore breed in Brazil may ignore the presence of GEI in their evaluations, since this has been reported as nonsignificant.

However, for other racial groups, the same conclusion cannot be extrapolated. The results obtained by Santana Jr. et al. (2014) for animals of the composite Montana breed and their crosses, presenting different racial compositions, evaluated in different cities distributed 
by the different Brazilian states, verified values of rg between 0.64 - 0.89 , which indicated the occurrence of IGA among some of the different breeding environments.

For the trait age at the first calving of the females, a pronounced effect of the GEI in all combinations involving the North region was found ( $\mathrm{rg}$ equal to 0.21 with the Central-west region and 0.52 with the Southeast). These results are due to marked differences in environmental and management conditions between the regions, since there is a greater similarity of the breeding environment in the Southeast and Central-west regions, as well as, management standardization due to the historical tradition of livestock farming of these regions.

These results were confirmed by Lemos et al. (2015), using evaluation by reaction norms, with animals of the same breed raised in different Brazilian states. In that study, rg values lower than 0.80 were found. The same was found by Ambrosini et al. (2016), where GEI effects on AFC were found in heifers created under different environmental gradients in the Northeast region of Brazil.

Evidence from the IGA was also found by Silveira et al. (2014), which carried out an evaluation between three different regions of the state of Mato Grosso do Sul, finding a significant effect of the interaction between the three regions. According to Raidan et al. (2015), traits of low heritability are more susceptible to the effects of GEI, which can be confirmed by the results found, with low-magnitude AFC heritability (0.117).

These results, that signalize the presence of GEI, indicate that different gene groups are acting in the phenotypic determination of the trait, or these genes are acting differently on the traits, which can be confirmed by the differences in the estimated heritabilities according to the environment. The presence of the interaction between the studied regions indicates that progenies of genetically superior animals in one region may not present the same results if their progenies are created in different regions.

\section{REFERENCES}

AMBROSINI, D.P.; MALHADO, C.H.M.; MARTINS FILHO, R.; CARDOSO, F.F.; CARNEIRO, P.L.S. Genotype $\mathrm{x}$ environmentinteractions in reproductivetraitsofNellorecattle in northeastern Brasil. Trop. Anim.

Health Prod. v.48, p.1401-1407, 2016.

BOLIGON, A.A.; RORATO, P.R.N.; ALBUQUERQUE, L.G. Correlações genéticas entre medidas de perímetro escrotal e características produtivas e reprodutivas de fêmeas da raça Neore. R. Bras. Zootec., v.36, n.3, p.565-571, 2007.

BOLIGON, A.A.; VOZZI, P.A.; NOMELINI, J.; RORATO, P.R.N.; BEZARRA, L.A.F.; LÔBO, R.B. Parâmetros genéticos para idade ao primeiro parto estimados por diferentes modelos para rebanhos da raça Nelore. Ciência Rural, v.38, n.2, p.432-436, mar-abr, 2008.

BRUMATTI, R.C.; FERRAZ, J.B.S.; E LER, J.P.; FORMIGONNI, I.B. Desenv olvimento de índice de seleção em gado de corte sob o enfoque de um modelo b ioeconômico. Archivos de

Zootecnia, v.60, p.205-213, 2011. BUZANSKAS, M.E.; PIRES, P.S.; CHUD T.C.S., BERNARDES P.A., ROLA L.D., SAVEGNAGO 


\section{R.P., LOBO R.B., MUNARI}

D.P. Parameterestimates for reproductiveandcarcasstraitsinNelorebe efcattle. Theriogenology, v.92, p. 204209. 2017.

CARVALHO, C.V.D. \&

BITTENCOURT, T.C.C. Breeding objectives for a Nellore catttle rearing system. Pesq. agropec. bras., v.50, n.9, p.814-820, set. 2015.

CHIAIA, H.L.; LEMOS, M.V.; VENTURINI, G.C.; ABOUJAOUDE, C.; BERTON, M.P.; FEITOSA, F.B.; CARVALHEIRO, R.;

ALBUQUERQUE, L.G.; OLIVEIRA, H.N.; BALDI, F. Genotype $\times$ environment interaction for age at first calving, scrotal circumference, and yearling weight in Nellore cattle using reaction norms in multitrait random regression models. J Anim Sci.

Apr;93(4):1503-10. 2015.

CHUD, T.C.S.; CAETANO, S.L.; BUZANSKAS, M.E.; GROSSI, D.A.; GUIDOLIN, D.G.F.; NASCIMENTO, G.B. Genetic analysis for gestation length, birth weight, weaning weight, and accumulated productivity in Nellore beef cattle. Livest. Sci., v.170, p. 16-21. 2014.

DIAZ, I.D.P.S.; OLIVEIRA, H.N.; BEZERRA, L.A.F.; LÔBO, R.B. Genotype by environment interaction in Nellore cattle from five Brazilian states. Genetic Molecular Biologi. v.34, p. 435-442, 2011.

FALCONER, D. S. The problem of environment and selection. American Naturalist, 86(830), 293-298, 1952. FARIA, C.U.; MAGNABOSCO, C.U.; ALBUQUERQUE, L.G.; LOS REYES, A.; BEZERRA, L.A.F.; LÔBO, R.B. Análise bayesiana na estimação de correlações genéticas entre escores visuais e características reprodutivas de bovinos Nelore utilizando modelos linear-limiar. Arq. Bras. Med. Vet. Zootec., Belo Horizonte, v. 61, n. 4, p. 949-958, Aug. 2009.

FERRAZ, J.B.S.; ELER, J. Seleção de Bosindicus para precocidade sexual.

Rev Bras ReprodAnim, v.31, p.167171, 2007.

FORTES, M.R.S.; LEHNERT, S.A.; BOLORMAA, S.; REICH, C.; FORDYCE, G.; CORBET, N.J. Finding genes for economically important traits: Brahman cattle puberty. Anim. Prod. Sci., v.52, p.143-50. 2012.

IBGE - Instituto Brasileiro de Geografia e Estatística. Pesquisa pecuária Municipal 2016. Disponível em: <https://sidra.ibge.gov.br/pesquisa/ppm/ quadros/brasil/2016> Consultado em 24 de junho de 2018.

IRANO, N.; CAMARGO, G.M.F.; COSTA, R.B.; TERAKADO, A.P.N.; MAGALHÃES, A.F.B.; SILVA, R.M.O.; DIAS, M.M.; BIGNARDI, A.B.; BALDI, F.; CARVALHEIRO, R.; OLIVEIRA, H.N.; ALBUQUERQUE, L.G. Genome-wideAssociationstudy for IndicatorTraitsof Sexual Precocity in NelloreCattle. PLoS ONE 11(8): e0159502, 2016.

JORGE JÚNIOR, J.; CARDOSO, V.L.; ALBUQUERQUE, L.G. de.

Objetivos de seleção e valores econômi cos em sistemas de produção de gado de corte no Brasil. Revista Brasileira de

Zootecnia, v.36, p.1549-1558, 2007. LEMOS, M.V.V; CHIAIA, H.L.J.; BERTON, M.P.; FEITOSA, F.L.B.; ABOUJAOUDE, C.; VENTURINI, G.C.; OLIVEIRA, H.N.; ALBUQUERQUE, L.G.; BALDI, F. 
Reaction norms for the study of genotype-environment interaction for growth and indicator traits of sexual precocity in Nellore cattle. Geneticsand Molecular Research. v.4, n.2, p. 71517162,2015

MATOS, A.S.; SENA, J.S.S.; MARCONDES, C.R.; BEZERRA, L.A.F.; LÔBO, R.B.; RORATO, P.R.N.; CUCCO, D.C.; ARAÚJO, R.O. Interação genótipo-ambiente em rebanhos nelore da Amazônia Legal.

Rev. Bras. Saúde Prod. Anim., Salvador, v.14, n.3, p.599-608 jul./set., 2013

McMANUS, C.; BARCELLOS,J.O.J.; FORMENTON, B.K.; HERMUCHE, P.M.; CARVALHO, O.A.JR.; GUIMARÃES, R. Dynamics of Cattle Production in Brazil. PLoS

ONE11(1):e0147138, 2016

MELLO, R.R.C.; FERREIRA, J.E.; SOUSA, S.L.G.; MELLO, M.R.B.; PALHANO, H.B. Parâmetros genéticos de características reprodutivas em bovinos de corte e leite. Rev. Bras.

Reprod. Anim., Belo Horizonte, v.40, n.2, p.65-72, abr./jun. 2016.

MISZTAL, I.; TSURUTA, S.; LOURENÇO, D.; AGUILAR, I.; LEGARA, A.; VITEZICA, Z. Manual for BLUPF90 familyofprograms. Athens: University of Georgia. Manual for BLUPF90 family of programs. Georgia: Athens: UniversityofGeorgia. 2014.

OLIVEIRA, J.H.F.; MAGNABOSCO, C.U.; BORGES, A.M.S.M. Nelore:

Base genética e evolução seletiva no Brasil. Planaltina, DF:

EmbrapaCerrados, 54p., 2002.
PÉGOLO, N.T.; OLIVEIRA, H.N.; ALBUQUERQUE, L.G.; BEZERRA, L.A.F. Genotype by environment interaction for 450-day weight of Nelore cattle analyzed by reaction norm models. Genet. Mol. Biol. v.32. p. 281287, 2009.

RAIDAN, F.S.S.; PASSAFARO, T.L.; FRAGOMENI, B.O.; JOSAHKIAN, L.A.; PEREIRA, I.G.; TORAL, F.L.B. Genotype $\times$ environment interaction in individual performance and progeny tests in beef cattle. J. Anim. Sci. v.93, p.920-933, 2015.

ROBERTSON, A. The sampling variance of genetic correlation coefficient. Biometrics, v.15, p.469485, 1959.

SANTANA JR, M.L.; ELER, J.P.; CARDOSO, F.F.; ALBUQUERQUE, L.G.; BALIEIRO, J.C.C.; PEREIRA, R.J.; FERRAZ, J.B.S. Genotype by environment interaction for postweaning weight gain, scrotal circumference, and muscling score of composite beef cattle in different regions of Brazil.

GeneticsandMolecular Research, v.13, n.2, p.3048-3059, 2014.

SILVEIRA, M. V., SOUZA, J.C. DE, SILVA, L.O.C., FREITAS, J.A., GONDO, A., FERRAZ FILHO, P.B. Interação genótipo $\mathrm{x}$ ambiente sobre características produtivas e reprodutivas de fêmeas nelore. Archivo Zootecnia. n.63, p.223-226, 2014.

SIQUEIRA, J.B.; GUIMARÃES, J.D.; PINHO, R.O. Relação entre perímetro escrotal e características produtivas e reprodutivas em bovinos de corte: uma revisão. Rev. Bras. Reprod. Anim., Belo Horizonte, v.37, n.1, p.3-13, jan./mar. 2013. 
SOUSA, G.G.T.; SANTOS, K.R.;

CAMPELO, J.E.G.; OLIVEIRA,

M.R.A.; PIRES, L.C.; PEREIRA, R.J.;

SOUSA, R.P.R.; SOUSA JÚNIOR,

S.C. Fatores ambientais e parâmetros

genéticos para características

reprodutivas de fêmeas Nelore na região

meio norte do Brasil. Rev. Bras. Saúde

Prod. Anim., Salvador, v.16, n.2,

p.290-299. abr./jun., 2015.

TORAL, F.L.B.; SILVA, L.O.C.;

MARTINS, E.L.; GONDO, A.

Interação genótipo-ambiente em características de crescimento de bovinos da raça Nelore no Mato Grosso do Sul. R. Bras. Zootec. v.33, p.14451455, 2004.

VAN TASSEL, C.P.; VAN VLECK, L.D. Multiple-trait gibbs sampler for animal models: flexible programs for bayesian and likelihood-based (co)variance component inference. Journal Animal Science, v.74, p.2586-2597, 1996. 